\title{
Seasonal variation in elytral colour polymorphism in Harmonia axyridis (the ladybird beetle): the role of non-random mating
}

\author{
NAOYA OSAWA $\&$ TAKAYOSHI NISHIDA \\ Laboratory of Entomology, Faculty of Agriculture, Kyoto University, Kyoto 606, Japan
}

\begin{abstract}
Seasonal variation in the frequency of elytral colour polymorphism in the ladybird beetle, Harmonia axyridis, was analysed through the combination of field observations and laboratory mate-choice experiments. Field observations involving daily mark-recapture of a local population revealed an overall preponderance of melanic morphs in the population, but the proportion of nonmelanics notably increased from spring to summer due to their higher frequency of mating among different morphs of the spring generation. In the laboratory experiments, both melanic and nonmelanic females preferentially chose non-melanic males in spring, but non-melanics were less successful at mating than melanics in summer. Therefore, the relative frequencies of melanics and non-melanics within a population vary throughout the seasons, with non-melanics increasing in proportion towards summer and decreasing thereafter. Laboratory experiments revealed that nonrandom mating among morphs is the basis of this variation, with females and, to a lesser degree, males being involved in the process of mate selection. The results of an artificial colour-change experiment indicate that male elytral colour is an important factor in female mate selection but other factors such as behaviour and chemical cues must also be involved.
\end{abstract}

Keywords: elytral colour polymorphism, Harmonia axyridis, ladybird beetle, mating preference, non-random mating, seasonal variation.

\section{Introduction}

Attention has been drawn to elytral colour polymorphism in coccinellids as an ideal subject of study in ecological genetics (Dobzhansky, 1933; Komai, 1956; Hodek, 1973). In Adalia bipunctata LinNe, which is widely distributed in Europe, melanic and non-melanic morphs have been recognized and interpreted as an adaptation to varying thermal environments within the geographical distribution of the species ('thermal melanism', Lusis, 1961; Benham et al., 1974; Muggleton et al., 1975; Creed, 1975; Brakefield, 1984a,b; Brakefield \& Willmer, 1985; Brakefield \& Lees, 1987; Stewart \& Dixon, 1989) or as a mechanism to reduce the non-melanic frequency by toxic substances of the polluted air in industrial areas ('industrial melanism', Creed, 1966, 1971a,b, 1974; Lees et al., 1973; Bishop et al., 1978). In north-eastern Asia, Harmonia axyridis PALLAs is known to have four elytral

†Correspondence. colour morphs, three of them being regarded as melanic and one as non-melanic (Hosino, 1936; Komai, 1956; Sasaji, 1971). Interestingly, the proportion of melanic morphs of this species increases towards southern districts, which Komai (1956) suggested as another form of climatic adaptation.

Past studies have considered colour polymorphism in coccinellids in terms of geographical clines (e.g. Komai, 1956; Scali \& Creed, 1975), whilst a few investigated temporal variations in morph frequency within a regional population (Timoféeff-Ressovsky, 1940; Tan, 1949). Nevertheless, note that geographical and temporal morph variation does not always correspond to what is expected from thermal and industrial adaptation theories (Bengtson \& Hagen, 1975, 1977; Honek, 1975; Muggleton, 1978). Furthermore, no previous investigation has revealed morph-related selective death in polymorphic ladybird beetles. It seems unlikely that thermal and/or industrial melanism hypotheses can fully explain the patterns of elytral colour polymorphism in coccinellids. 
Apart from external factors, such as thermal and industrial stresses, which can effect polymorphic characters, non-random mating among different morphs constitutes an important mechanism affecting the maintenance of polymorphism in a population, with different patterns of mating being associated with different fitness consequences (Partridge \& Halliday, 1984). In $A$. bipunctata, non-random mating as well as behaviour-based mate choice have been observed (Muggleton, 1978, 1979; Majerus et al., 1982a,b, 1986; O’Donald \& Muggleton, 1979; O'Donald et al., 1984; Brakefield, 1984c; Kearns et al., 1990). Very few studies, however, have demonstrated fitness consequences of non-random mating in field populations of polymorphic coccinellids, mainly due to the difficulty of quantitatively observing mating in a highly mobile and dispersive species. The present study combines intensive field observations and laboratory mate choice experiments to elucidate the temporal patterns of polymorphism in $H$. axyridis in central Japan. The main focus of analysis is the role of non-random mating in relation to seasonal variation rather than a fixed trend through the year.

\section{Materials and methods}

\section{The ladybird beetle}

$H$. axyridis typically has four elytral colour morphs: succinea $[h$, orange with some or no black spot $(s)]$, axyridis ( $h^{\mathrm{X}}$, black with some red spots), spectabilis $\left(h^{\mathrm{S}}\right.$, black with four red spots), and conspicua ( $h^{\mathrm{C}}$ black with two red spots) (see Komai, 1956). The genes that control colour morphs form multiple-alletic series, with the dominance order of $h<h^{\mathrm{X}}<h^{\mathrm{S}}<h^{\mathrm{C}}$ (Hosino, 1933, 1936; Tan \& Li, 1934). Following previous works (Hosino, 1936; Komai, 1956; Sasaji, 1971) beetles with black elytra (axyridis, spectabilis, and conspicua) were regarded as melanic and those with orange elytra (succinea) as non-melanic in this study.

The ladybird beetle has two or three generations in a year (Okada et al., 1973; Osawa, 1991). In the study area, adults of the overwintering generation terminate hibernation in late March and mate and lay eggs in April and May. Adults of the first generation emerge in mid May to June. In mid summer, the beetles seem to aestivate, although no detailed information is available. Adults of the second and/or third generations reappear in autumn and gradually aggregate at hibernation sites in early November (Obata, 1986). In this paper, the overwintering generation is referred to as the spring generation and the first generation as the summer generation.

\section{Field observations}

All observations were done in the Botanical Garden $\left(\sim 10,000 \mathrm{~m}^{2}\right)$ of Kyoto University $\left(35^{\circ} 02^{\prime} \mathrm{N}\right.$ $\left.135^{\circ} 47^{\prime} \mathrm{W}\right)$, central Japan. Every day from early April to early August in 1985, 1987, and 1988, adults were captured and individually marked by four dots with quick drying paint and also by drilling tiny holes to prevent the paint from falling off. Newly marked individuals were released at the site where they were caught after recording body size (total body length to the nearest $0.01 \mathrm{~mm}$, recorded in 1987 and 1988), sex, elytral colour, whether mating or not at the time of capture, code of a mate and site of capture. For all recaptured beetles, individual code, sex, whether mating or not at the time of recapture, code of a mate and the recapture site were recorded. A total of 2,572 individuals were thus observed.

Individuals of the summer generation were distinguished from those of the spring generation on the basis of pale and soft elytra of newly emerged adults (cf. Brakefield, 1984a).

Endler's (1986) selection coefficient, $S$, was used to assess the relative frequencies of morphs in the spring and summer generations. Mating preference in the field population was analysed using Manly's (1985) mating preference coefficient $(\beta)$, which measures deviation from random mating among morphs in a finite population (cf. Spencer, 1988). When a random sample of non-mating individuals contains a total of $a_{i}$ males and $b_{i}$ females of morph type $i$ and a random sample of mating individuals contains $d_{i j}$ pairs of morph $i$ male-morph $j$ female $(i, j=1-K)$, the preference coefficient for $i-j$ pairing is given as

$\hat{\beta}=\left[d_{i j} /\left(a_{i} b_{i}\right)\right] /\left[\sum_{r=1}^{K} \sum_{s=1}^{K} d_{r s} /\left(a_{i} b_{s}\right)\right]$.

\section{Laboratory experiments of mate choice}

Four different experiments were carried out in the laboratory at $25^{\circ} \mathrm{C}$ and $16 \mathrm{~L}-8 \mathrm{D}$, using beetles collected from the field as adults (spring generation, immediately after hibernation) and as pupae (summer generation), and maintained as mass culture in unisexual groups of two to five individuals. Beetles were reared on aphids Aphis spiraecola VAN DER GOOT and Myzus varians DAVIDSON. The experimental arena was a Petri dish $(9 \mathrm{~cm}$ in diameter and $2 \mathrm{~cm}$ in height) to which different combinations of male and female morphs were introduced. An experimental session consisted of a 30-min continuous observation of mating activities, counting all successful and unsuccessful mating attempts; this was replicated 18-60 times 
using different individuals from the stock culture. In all the sessions, copulating pairs were artificially separated after 2 min of copulation and released again in the same experimental arena. Beetles which continued genital contact for 2 min were regarded as having completed copulation; in a separate observation 78 per cent of matings lasting $2 \mathrm{~min}$ reached the body shaking' stage, which signals sperm transfer in this species (Obata, 1987). Melanic and non-melanic morphs used in the experiments (Experiment 2, 3, and 4) were conspicua and succinea, respectively.

Experiment 1. Free mate choice experiment. Four individuals (male and female, one individual per morph per sex) were introduced. A total of 60 replicated sessions were performed.

Experiment 2. Female choice experiment. One female (melanic or non-melanic) and two males (one melanic and one non-melanic) were kept together. Eighteen replications.

Experiment 3. Male choice experiment. One male (melanic or non-melanic) and two females (one melanic and one non-melanic) were kept together. Twenty replications.

Experiment 4. Artificial colour-change experiment. One female (melanic or non-melanic) and two males (one melanic and one non-melanic) painted with quick drying paint (reverse-coloured pair - one melanic male painted orange and non-melanic painted black with red spots, or duplicate-coloured pair - one melanic male painted black with red spots and nonmelanic painted orange) were observed. The paints used were Magic Ink ${ }^{\circledast}$ No. 500 for black and Mitsubishi Paint Marker ${ }^{\circledR}$ PX-20 for orange and red. The use of these paints did not appear to affect the beetles adversely (see Results). Beetles were kept for 4-5 min in Petri dishes, to dry the paints completely, before being used in the experiment. Twenty replications.

\section{Results}

\section{Morph frequencies and mating patterns}

Figure 1 shows the frequencies of four morphs in terms of phenotype and allele in the spring and summer generation. Whilst conspicua was dominant in all the cases, there was a notable trend for non-melanic succinea to increase in frequency from spring to summer in each year, which is also confirmed by an analysis of the selection coefficient, $S$, of non-melanics against melanics in phenotype and allele (Table 1).
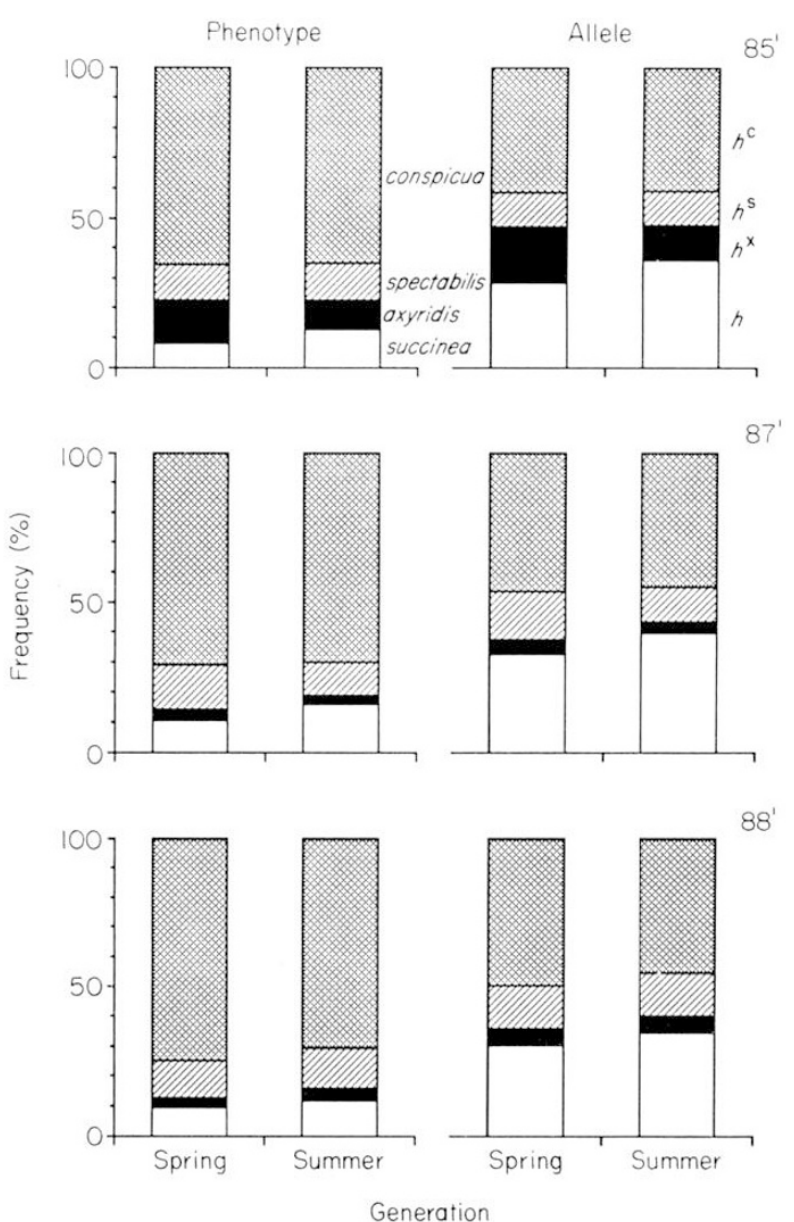

Fig. 1 Morph frequencies in phenotype and allele in spring and summer generation.

Table 1 Selection coefficient of non-melanics against melanics from spring to summer generation, with respect to phenotype and allele. Significance is indicated by probability values

\begin{tabular}{lll}
\hline Year & Phenotype & Allele \\
\hline 1985 & $0.410(P<0.05)$ & $0.295(P<0.05)$ \\
1987 & $0.375(P<0.001)$ & $0.272(P<0.001)$ \\
1988 & $0.251(0.05<P<0.10)$ & $0.174(P<0.05)$ \\
Total & $0.366(P<0.001)$ & $0.262(P<0.001)$ \\
\hline
\end{tabular}

One crucial factor, which determines morph frequencies in one generation, is the pattern of mating in the previous generation. Morph frequencies among non-mating and mating individuals observed in the field are shown in Fig. 2. In the spring generation, frequencies of four morphs among mating individuals (males and females combined) were significantly different $\left(\chi^{2}=16.9\right.$, d.f. $\left.=3, P<0.001\right)$ from those of nonmating individuals. When sexes were treated 


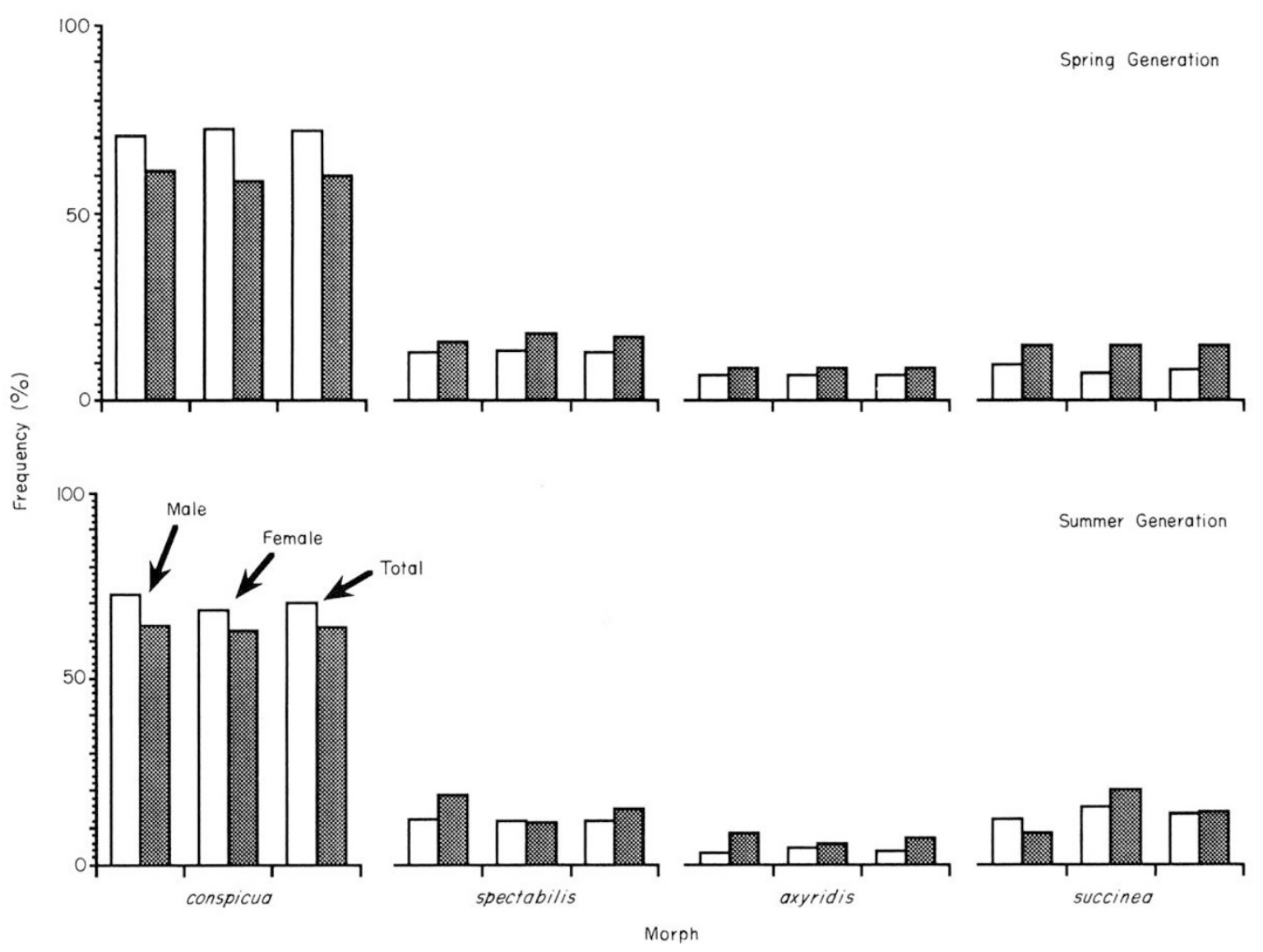

Fig. 2 Frequencies of different morphs among non-mating ( $\square$ ) and mating ( $)$ individuals.

separately, the difference in morph frequency between mating and non-mating individuals was more pronounced in females $\left(\chi^{2}=11.7\right.$, d.f. $\left.=3, P<0.01\right)$ than in males $\left(\chi^{2}=5.67\right.$, d.f. $\left.=3,0.10<P<0.20\right)$. Nevertheless, in both males and females the difference was largely due to a significantly smaller proportion of conspicua being represented among mating as against nonmating individuals, while the reverse was true for succinea. Thus, succinea demonstrated a disproportionately large frequency of mating in the spring generation.

A different pattern of mating was observed in the summer generation, where males but not females showed a significant difference in morph frequency between mating and non-mating individuals (males, $\chi^{2}=8.05$, d.f. $=3, P<0.05$; females, $\chi^{2}=1.41$, d.f. $=3$, $0.70<P<0.80$ ). In the case of males, the difference was due to a high proportion of spectabilis and a low proportion of conspicua among mating individuals. When males and females were combined, the difference in morph frequency was only marginally significant $\left(\chi^{2}=5.28\right.$, d.f. $\left.=3, \quad 0.10<P<0.20\right)$. Notably males and females of succinea showed neither signifi- cantly increased nor reduced frequency of mating compared with three melanic morphs in this generation.

Mating preferences among morphs were further analysed by Manly's preference coefficient, $\beta$ (Table 2 ), with twice the value of S.E. being used as a criterion for judging a departure from random mating at $\sim 5$ per cent level of significance (Manly, 1985). Of 16 possible pairs among four morphs, three pairs, all involving conspicua, had a significantly small value of $\beta$, whilst none involving succinea did so in the spring generation. In the summer generation, only one pair (conspicuaconspicua) had a significantly small value. Thus melanics may be expected to decrease in frequency among the offspring of the spring generation (i.e. summer generation), while the effect of the low frequency of conspicua-conspicua pairing in the summer generation may be obscured by intra-melanic pairings.

\section{Adult body size and mating}

Body size constitutes an important trait which could influence behaviour, competitive capacity, fecundity and the longevity of organisms. It is therefore worth- 
Table 2 Estimates of the preference coefficient $\beta$

\begin{tabular}{|c|c|c|c|c|c|c|c|c|c|}
\hline \multirow{3}{*}{$\begin{array}{l}\text { Male } \\
\text { morph }\end{array}$} & \multicolumn{9}{|c|}{ Female morph } \\
\hline & \multicolumn{2}{|c|}{ conspicua } & \multicolumn{2}{|c|}{ spectabilis } & \multicolumn{2}{|l|}{ axyridis } & \multicolumn{2}{|c|}{ succinea } & \multirow[b]{2}{*}{ Total $\beta$} \\
\hline & $\beta$ & S.E. & $\beta$ & S.E. & $\beta$ & S.E. & $\beta$ & S.E. & \\
\hline \multicolumn{10}{|c|}{ Spring generation } \\
\hline conspicua & $0.025^{*}$ & 0.001 & 0.052 & 0.007 & $0.026^{*}$ & 0.008 & 0.077 & 0.013 & 0.180 \\
\hline spectabilis & $0.038^{*}$ & 0.007 & 0.070 & 0.035 & 0.174 & 0.086 & 0.085 & 0.066 & 0.367 \\
\hline axyridis & 0.054 & 0.012 & 0.038 & 0.041 & 0.070 & 0.096 & 0 & - & 0.162 \\
\hline succinea & 0.051 & 0.008 & 0.051 & 0.033 & 0.048 & 0.057 & 0.140 & 0.086 & 0.290 \\
\hline Total $\beta$ & 0.168 & & 0.211 & & 0.318 & & 0.302 & & \\
\hline \multicolumn{10}{|c|}{ Summer generation } \\
\hline conspicua & $0.029^{*}$ & 0.008 & 0.038 & 0.024 & 0.054 & 0.052 & 0.050 & 0.024 & 0.171 \\
\hline spectabilis & 0.053 & 0.029 & 0.077 & 0.096 & 0 & - & 0.089 & 0.087 & 0.219 \\
\hline axyridis & 0.130 & 0.098 & 0 & - & 0.417 & 0.829 & 0 & - & 0.547 \\
\hline succinea & 0.033 & 0.023 & 0 & - & 0 & - & 0.030 & 0.051 & 0.063 \\
\hline Total $\beta$ & 0.245 & & 0.115 & & 0.471 & & 0.169 & & \\
\hline
\end{tabular}

*Significantly different from the non-selection value of $1 / 16=0.0625$ at approximately the 5 per cent level of significance.

Table 3 Body size (total body length in millimetre) of different morphs

\begin{tabular}{|c|c|c|}
\hline \multirow[b]{2}{*}{ Morph } & Female & Male \\
\hline & Mean \pm S.E. $(n)$ & Mean \pm S.E. $(n)$ \\
\hline \multicolumn{3}{|c|}{ Spring generation } \\
\hline conspicua & $6.63 \pm 0.04(179)$ & $6.17 \pm 0.04(130)$ \\
\hline spectabilis & $6.77 \pm 0.08(31)$ & $6.05 \pm 0.08(22)$ \\
\hline axyridis & $6.75 \pm 0.16(11)$ & $6.06 \pm 0.33(5)$ \\
\hline succinea & $6.86 \pm 0.10(33)$ & $6.00 \pm 0.10(20)$ \\
\hline \multicolumn{3}{|c|}{ Summer generation } \\
\hline conspicua & $6.75 \pm 0.04(241)$ & $6.14 \pm 0.03(208)$ \\
\hline spectabilis & $6.76 \pm 0.09(43)$ & $6.18 \pm 0.07(41)$ \\
\hline axyridis & $6.78 \pm 0.11(13)$ & $6.32 \pm 0.15(12)$ \\
\hline succinea & $6.66 \pm 0.07(56)$ & $6.22 \pm 0.08(29)$ \\
\hline
\end{tabular}

while to analyse the variation in body size among four morphs of $H$. axyridis under study. Table 3 shows the mean body size of each morph for males and females separately. Among females of the spring generation, a difference in body size was marginally significant (ANOVA: d.f. $=3, S S=1.80, F=2.15,0.05<P<0.10$ ) with succinea being the largest and conspicua the smallest. Males of the spring generation did not show a significant difference in size between morphs. In the summer generation, neither males nor females demonstrated a significant difference, though female succinea appeared to be slightly smaller than three melanic morphs and male axyridis slightly larger than other morphs.

When body size was compared between non-mating and mating individuals (Table 4), only males of the

Table 4 Comparison of body size of non-mating and mating beetles

\begin{tabular}{llll}
\hline & \multicolumn{2}{l}{ Body size, mean \pm S.E. $(n)(\mathrm{mm})$} & \\
\cline { 2 - 3 } & Non-mating & Mating & $P(t$-test $)$ \\
\hline $\begin{array}{llll}\text { Spring generation } \\
\quad \text { Female }\end{array}$ & & \\
$\quad$ Male & $6.70 \pm 0.04(180)$ & $6.66 \pm 0.06(74)$ & $>0.30$ \\
$\quad \begin{array}{l}\text { Summer generation } \\
\quad \text { Female }\end{array}$ & $6.08 \pm 0.04(22)$ & $6.25 \pm 0.06(55)$ & $<0.05$ \\
$\quad$ Male & $6.74 \pm 0.03(291)$ & $6.72 \pm 0.06(62)$ & $>0.30$ \\
\hline
\end{tabular}


Table 5 ANOva of minimal adult life span

\begin{tabular}{lllll}
\hline Source & d.f. & SS & $F$ & $P$ \\
\hline Body size (B) & 1 & 20.9 & 0.67 & 0.41 \\
Morph (M) & 3 & 76.2 & 0.81 & 0.49 \\
Sex (S) & 1 & 10.3 & 0.33 & 0.57 \\
$\mathrm{~B} * \mathrm{M}$ & 3 & 72.2 & 0.77 & 0.51 \\
$\mathrm{~B} * \mathrm{~S}$ & 1 & 13.3 & 0.42 & 0.51 \\
$\mathrm{M} * \mathrm{~S}$ & 3 & 42.1 & 0.45 & 0.72 \\
$\mathrm{~B} * \mathrm{M} * \mathrm{~S}$ & 3 & 34.3 & 0.36 & 0.78 \\
\hline
\end{tabular}

spring generation demonstrated a significant difference; mating individuals were larger than non-mating ones. On the other hand, the fact that females did not show a significant difference in spring may at first sight seem contradictory to the results of Table 3; note here that succinea was less abundant than conspicua, thus the effect of a slightly larger body of succinea was damped by smaller but more abundant conspicua in the calculation of mean body size.

An observed high frequency of mating of a particular morph may simply result from that morph being longer-lived than others, rather than from it being more abundant in absolute numbers. In the present study there was no significant difference in minimal adult life span (i.e. time between first capture of an individual and its last observation in the field) in terms of body size, morph, sex and their interactions (Table 5).

\section{Mate choice experiments}

Table 6 summarizes the results of a multiple mate choice experiment (Experiment 1) involving four males and four females of different morphs. In the spring generation, males of non-melanic succinea achieved a significantly higher frequency of mating than other melanic males $\left(\chi^{2}=79.8\right.$, d.f. $\left.=3, P<0.001\right)$. Conversely, male conspicua had the lowest mating frequency coupled with a high refusal rate ( 37.9 per cent of all mating attempts). Amongst females, melanic spectabilis had a significantly low frequency of mating compared with others $\left(\chi^{2}=18.3\right.$, d.f. $\left.=3, P<0.001\right)$. All these phenomena potentially contribute to increasing the proportional abundance of non-melanic succinea against that of melanic morphs in a subsequent generation. In contrast to the spring generation, males of the summer generation did not demonstrate a statistically significant difference in mating frequency among different morphs $\left(\chi^{2}=2.53\right.$, d.f. $=3,0.30$ $<P<0.50)$, although the highest incidence recorded for spectabilis may agree with the field data of Fig. 2, where they were observed with a disproportionately high frequency of mating. Among females of the summer generation, the difference in the frequency of successful mating among morphs was marginally significant $\left(\chi^{2}=7.37\right.$, d.f. $\left.=3,0.05<P<0.10\right)$, with conspicua being associated with the highest frequency and the lowest refusal rate ( 10.6 per cent). Thus, a general trend in the summer generation is towards a slight

Table 6 Total number of successful and unsuccessful (refused by females, in parenthesis) mating attempts observed for different morph combinations in the free mate choice experiment with multiple males and females (Experiment 1)

\begin{tabular}{|c|c|c|c|c|c|}
\hline & \multicolumn{4}{|c|}{ Female morph } & \multirow[b]{3}{*}{ Total } \\
\hline & \multicolumn{3}{|l|}{ Melanic } & \multirow{2}{*}{$\frac{\text { Non-melanic }}{\text { succinea }}$} & \\
\hline & conspicua & spectabilis & axyridis & & \\
\hline \multicolumn{6}{|l|}{ Spring generation } \\
\hline Male morph conspicua & $12(4)$ & $6(6)$ & $8(7)$ & $10(5)$ & $36(22)$ \\
\hline Melanic spectabilis & $13(5)$ & $6(5)$ & $21(9)$ & $13(3)$ & $53(22)$ \\
\hline axyridis & $12(1)$ & $7(7)$ & $10(1)$ & $11(6)$ & $42(15)$ \\
\hline Non-melanic succinea & $38(4)$ & $15(15)$ & $34(13)$ & $38(10)$ & $125(42)$ \\
\hline Total & $75(14)$ & $34(33)$ & $73\langle 30\rangle$ & $72(24)$ & \\
\hline \multicolumn{6}{|l|}{ Summer generation } \\
\hline Male morph conspicua & $17(4)$ & $11(4)$ & $17(2)$ & $17(5)$ & $62(15)$ \\
\hline Melanic spectabilis & $22(1)$ & $19(5)$ & $21(3)$ & $11(3)$ & $73(12)$ \\
\hline axyridis & $14(2)$ & $17(10)$ & $18(7)$ & $11(10)$ & $60(29)$ \\
\hline Non-melanic succinea & $23(2)$ & $9(8)$ & $14(2)$ & $10(3)$ & $56(15)$ \\
\hline Total & $76(9)$ & $56(27)$ & $70(14)$ & $49(21)$ & \\
\hline
\end{tabular}


advantage for melanics at the expense of non-melanic succinea.

In the female choice experiment (Experiment 2, Table 7), where a female was offered a melanic (conspicua) and a non-melanic (succinea) male, nonmelanic males were chosen more frequently than melanics by both melanic and non-melanic females (melanic females, $\chi^{2}=4.00$, d.f. $=1, P<0.05$; nonmelanic females, $\chi^{2}=13.5$, d.f. $=1, P<0.001$ ) in the spring generation. In contrast, no preference towards either melanic or non-melanic male was demonstrated by females in the summer generation. On the other hand, note that females of melanic conspicua tended to mate more frequently with a lower rate of refusal (11.1 per cent, melanic and non-melanic males combined) than females of non-melanic succinea (28.1 per cent) in summer.

Males put in a position to choose either a melanic or non-melanic female (Experiment 3, Table 8) showed no significant difference in the frequency of mating with a melanic versus non-melanic female in the spring generation (melanic, $\chi^{2}=0.10$, d.f. $=1, P>0.90$; nonmelanic, $\chi^{2}=0.68$, d.f. $\left.=1,0.30<P<0.50\right)$. However, in the summer generation both melanic and nonmelanic males seemed to mate more frequently with melanic females $\left(\chi^{2}=3.00\right.$, d.f. $=1,0.05<P<0.10$, melanic and non-melanic males combined); this is in agreement with the tendency observed in Experiment 2.

Finally, the results of the elytral colour-change experiment (Experiment 4) are summarized in Table 9, where information from Table 7 is also incorporated for comparison. In the spring generation, whilst unpainted male conspicua (melanic) are clearly less successful at mating than unpainted succinea (nonmelanic), the former's chance of mating was substantially improved when reverse-painted (i.e. in the same colour as non-melanic succinea $)\left(\chi^{2}=4.59\right.$, d.f. $=1$, $0.01<P<0.05)$, this trend being particularly notable with female succinea $\left(\chi^{2}=30.9\right.$, d.f. $\left.=1, P<0.001\right)$; on

Table 7 Total number of successful and unsuccessful mating attempts in the female choice experiment (Experiment 2)

\begin{tabular}{|c|c|c|c|c|}
\hline \multirow[b]{3}{*}{ Male morph } & \multicolumn{4}{|c|}{ Female morph } \\
\hline & \multicolumn{2}{|c|}{ Melanic (conspicua) } & \multicolumn{2}{|c|}{ Non-melanic (succinea } \\
\hline & Mated & Refused & Mated & Refused \\
\hline \multicolumn{5}{|l|}{ Spring generation } \\
\hline Melanic (conspicua) & 12 & 15 & 3 & 9 \\
\hline Non-melanic (succinea) & 24 & 10 & 21 & 8 \\
\hline \multicolumn{5}{|l|}{ Summer generation } \\
\hline Melanic (conspicua) & 16 & 1 & 12 & 5 \\
\hline Non-melanic (succinea) & 16 & 3 & 11 & 4 \\
\hline
\end{tabular}

Table 8 Total number of successful and unsuccessful mating attempts in the male choice experiment (Experiment 3 )

\begin{tabular}{|c|c|c|c|c|}
\hline \multirow[b]{3}{*}{ Female morph } & \multicolumn{4}{|c|}{ Male morph } \\
\hline & \multicolumn{2}{|c|}{ Melanic (conspicua) } & \multicolumn{2}{|c|}{ Non-melanic (succinea) } \\
\hline & Mated & Refused & Mated & Refused \\
\hline \multicolumn{5}{|l|}{ Spring generation } \\
\hline Melanic (conspicua) & 19 & 13 & 21 & 2 \\
\hline Non-melanic (succinea) & 21 & 15 & 16 & 2 \\
\hline \multicolumn{5}{|l|}{ Summer generation } \\
\hline Melanic (conspicua) & 12 & 2 & 18 & 1 \\
\hline Non-melanic (succinea) & 7 & 2 & 11 & 1 \\
\hline
\end{tabular}


Table 9 Total number of successful and unsuccessful (in parenthesis) mating attempts observed in the artificial colour-change experiment (Experiment 4)

\begin{tabular}{|c|c|c|c|c|c|c|}
\hline \multirow[b]{3}{*}{ Female morph } & \multicolumn{6}{|c|}{ Male morph and treatment } \\
\hline & \multicolumn{2}{|l|}{ Unpainted } & \multicolumn{2}{|c|}{ Reverse-coloured } & \multicolumn{2}{|c|}{ Duplicate-coloured } \\
\hline & conspicua & succinea & conspicua & succinea & conspicua & succinea \\
\hline \multicolumn{7}{|c|}{ Spring generation } \\
\hline conspicua & $12(15)$ & $24(10)$ & $23(18)$ & $23(6)$ & $3(6)$ & $11(0)$ \\
\hline succinea & $3(9)$ & $21(8)$ & $32(6)$ & $15(8)$ & $5(21)$ & $13(1)$ \\
\hline \multicolumn{7}{|c|}{ Summer generation } \\
\hline conspicua & $16(1)$ & $16(3)$ & $20(3)$ & $28(3)$ & $19(3)$ & $12(2)$ \\
\hline succinea & $12(5)$ & $11(4)$ & $31(1)$ & $27(2)$ & $21(0)$ & $30(4)$ \\
\hline
\end{tabular}

the other hand, the reverse-painted male succinea (i.e. coloured as melanic conspicua) demonstrated little change in mating success. When males of conspicua and succinea were painted with their original colours ('duplicate-colouring'), the pattern of mating was basically the same as in the unpainted control $\left(\chi^{2}=0.04\right.$, d.f. $=1, \quad 0.80<P<0.90$, with female conspicua; $\chi^{2}=0.41$, d.f. $=1, \quad 0.50<P<0.70$, with female succinea); succinea males mated more frequently than conspicua with both melanic and non-melanic females. In the summer generation, neither reverse- nor duplicate-colouring seemed to alter the pattern of mating; males of conspicua and succinea had a roughly comparable mating success.

\section{Discussion}

Geographical variation in morph frequency has extensively been studied in the European coccinellid Adalia bipunctata, with physiological background to support the thermal melanism hypothesis (e.g. Brakefield \& Willmer, 1985; Stewart \& Dixon, 1989). In contrast, seasonal variation in morph frequency has received less attention and virtually no study has integrated field and laboratory investigations. Timoféeff-Ressovsky (1940) observed an increase in the frequency of melanics as against non-melanics from spring to autumn within a population of $A$. bipunctata in Germany, and suggested that melanics had a higher mortality in winter and were more active in spring. In Harmonia axyridis, Tan (1949) suggested that spring and summer climate were more favourable to conspicua (melanic) while the autumn climate was more favourable to succinea (non-melanic). Despite these earlier works, no detailed study has been undertaken to relate field observations on seasonal morph variation to mating behaviour, although the phenomenon of non- random mating is well known in $A$. bipunctata (cf. Muggleton, 1978, 1979; Kearns et al., 1990). Because morph variations can be subtle, a clear pattern may not emerge from either field or laboratory investigations alone; a combination of the two is most desirable in this respect.

The present study has demonstrated that an increase in the frequency of non-melanic morph (succinea) from the spring to the summer generation is related to nonrandom mating among different morphs. Evidence to this effect is that, in spring (i) both males and females of non-melanic succinea mate more frequently than melanic conspicua in the field, the latter being associated with a low selection coefficient, $S$; (ii) male succinea are more successful at mating than other morphs, particularly conspicua, in laboratory Experiment 1 and 2 ; (iii) female spectabilis (melanic) are less successful at mating than other morphs in Experiment 1. Note that, while the advantage of male succinea is evident in both field and laboratory results, the success of female succinea is confirmed only in the field. Similarly, the disadvantage of female succinea is confirmed only in the field. Similarly, the disadvantage of female spectabilis, which apparently occurs in the laboratory but is not evident in the field. These point to the subtleties of observed phenomena which are subjected to sampling biases under field or laboratory conditions. Nevertheless, all these observations concur with the general pattern of increasing non-melanic succinea from spring to summer, thus giving support to the view that non-random mating forms a basis of seasonal morph frequency variations. In addition to mating patterns, the fact that female succinea of the spring generation are larger in body size than other morphs, particularly conspicua, could contribute to their increase in the subsequent generation, probably through their higher fecundity and/or better survival of eggs and hatched larvae. 
Different mating patterns are seen in the summer generation in comparison with the spring generation. Male spectabilis (melanic) mate more frequently than other morphs in the field and in Experiment 1, although the trend is only marginally significant in the latter. Similarly, while female conspicua (melanic) engaged in mating more frequently than female succinea (non-melanic) (Experiments 2 and 3), the former's advantage is more modest among four morphs (Experiment 1). Note that male succinea, which shows an overwhelming mating advantage in spring over other morphs in both field and laboratory investigations, demonstrates no such trend in summer. All these observations of the summer generation suggest an overall increase in melanics against nonmelanics, thus reversing the trend seen in spring.

One of the most interesting results of the present study concerns the varying effects of elytral colourchange (Experiment 4) on mating success. The fact that male conspicua substantially improve their mating success when painted as non-melanic succinea suggests that (i) colour serves as a strong cue to induce mating, particularly among females, and (ii) females respond positively to the colouring of succinea, at least in spring. On the other hand, elytral colour cannot be the only factor involved in male mating success because the frequency of mating of non-melanic succinea, even when painted as disadvantaged melanic conspicua, shows no perceptible decline. Therefore, non-melanic succinea must also have chemically or physiologically based attractiveness which is independent of elytral colours. This dual interaction of elytral colour and other non-colour factor(s) in attracting a mate has never been demonstrated for coccinellid species. Furthermore, the present study also shows that the attractiveness of the traits varies temporally, as is evident in the changing patterns of mating from the spring to the summer generation. Thus, frequencies of morphs change as patterns of non-random mating change on a seasonal basis.

It has been suggested for $A$. bipunctata, that nonrandom mating is closely linked to mate choice by females (Muggleton, 1979; Majerus et al., 1982a,b; Kearns et al., 1990). In the present study, female mate choice is clearly implicated in the spring results of Experiments 1 and 2, where males of non-melanic succinea achieved a higher frequency of mating than other morphs. Similarly, the role of female mate choice appears decisive in the artificial colour-change experiment, as mentioned above. On the other hand, the possibility of male mating preference cannot be negated because in the summer generation females of melanic conspicua were apparently more successful at mating than females of succinea in Experiments 2 and
3, which implies some kind of choice on the part of males. In addition, field observations reveal that mating males were larger than non-mating ones in the spring generation, which suggests that size-related male-male competition must also be involved. At the same time, differential attractiveness or receptiveness of female morphs to males may also play a part in male mate choice. Thus, several different factors rather than a single factor seem to be concurrently influencing mating patterns in this species.

That the proportion of non-melanic individuals of $H$. axyridis increases towards the summer may be interpreted to conform to the thermal melanism hypothesis, in that non-melanics suffer less from overheating than melanics under strong irradiation in spring-summer (cf. Brakefield \& Willmer, 1985; Stewart \& Dixon, 1989). However, the fact that melanic conspicua is dominant in terms of numbers in both spring and summer, despite an increased proportion of nonmelanic succinea, and that there is no significant difference in the adult minimum life span among morphs, suggests that thermal melanism is a weak, if not totally insignificant, factor in the seasonal variation of colour polymorphism in $H$. axyridis. Komai's (1956) observation that melanic morphs of this species increase in frequency towards lower latitudes also contradicts the thermal melanism hypothesis. Thus, the maintenance of polymorphic characters in $H$. axyridis needs to be sought in other mechanisms.

The behavioural basis of non-random mating in $H$. axyridis appears to be fairly complex. Although females seem to have more potential for being choosy, particularly by refusing to mate with a certain male (Obata, 1987, 1988), the present study suggests that males could also exert their choosiness by mating preferentially with certain females (cf. Experiment 3 ). Whether such choosiness is freely expressed under natural conditions, however, remained to be explored. Nevertheless, it is notable that a change in mating preference from one generation to another corresponds to a cyclic variation in morph frequency as observed in the field population. Further investigation is necessary to unravel the adaptive significance of this phenomenon.

\section{Acknowledgements}

We are deeply indebted to Dr M. Tokeshi, Trinity College, for his helpful comments to improve this manuscript and correct the English. We would like to thank Professor I. Hodek and Dr O. Nedved, Czechoslovaki Academy of Sciences, for their comments on the first draft of this manuscript. We are also indebted to Professor E. Kuno, Kyoto University, for his invalu- 
able suggestions and continuous encouragement during this study. Thanks are also due to Professor H. Takada, Kyoto Prefectural University, for the identification of aphid species, Professor S. Kuroiwa and H. Tsuji, Kyoto University for permitting us to conduct this study in the Botanical Garden, Kyoto University, and Ms H.-F. Cheng, for her invaluable help with the laboratory experiments. Computations were performed with a FACOM-M780/30 computer at the Data Processing Center, Kyoto University. This study was supported in part by a Grant-in-Aid (No. 02954077, to N. Osawa) from the Ministry of Education, Science and Culture, Japan and a Grant-in-Aid (Biocosmos Program BCP 92-I-B-X, to T. Nishida) from the Ministry of Agriculture and Fisheries, Japan.

\section{References}

BENGTSON, S.-A. AND HAGEN, R. 1975. Polymorphism in the twospot ladybird Adalia bipunctata in western Norway. Oikos, 26, 328-331.

BENGTSON, S.-A. AND HAGEN, R. 1977. Melanism in the two-spot ladybird Adalia bipunctata in relation to climate in western Norway. Oikos, 28, 16-19.

BENHAM, B. R., LONSDALE, D. AND MUGGLETON, J. 1974. Is polymorphism in two-spot ladybird an example of non industrial melanism? Nature, 249, 179-180.

BISHOP, J. A., COOK, L. M. AND MUGGLETON, J. 1978. The response of two species of moths to industrialization in north west England. 1. Polymorphism for melanism. Phil. Trans. $R$. Soc. Lond. B, 218, 489-515.

BRAKEFIELD, P. M. 1984a. Ecological studies on the polymorphic ladybird Adalia bipunctata in The Netherlands. I. Population biology and geographical variation of melanism. J. Anim. Ecol., 53, 761-774.

BRAKEFIELD, P. M. 1984b. Ecological studies on the polymorphic ladybird Adalia bipunctata in The Netherlands. II. Population dynamics, differential timing of reproduction and thermal melanism. J. Anim. Ecol., 53, 775-790.

BRAKEFIELD, P. M. 1984c. Selection along clines in the ladybird Adalia bipunctata in The Netherlands: a general mating advantage to melanics and its consequences. Heredity, 53, 37-49.

BRAKEFIELD, P. M. AND LEES, D. R. 1987. Melanism in Adalia ladybirds and declining air pollution in Birmingham. Heredity, 59, 273-277.

BRAKEFIELD, P. M. AND WILLMER, P. G. 1985. The basis of thermal melanism in the ladybird Adalia bipunctata: differences in reflectance and thermal properties between the morphs. Heredity, 54, 9-14.

CREED, E. R. 1966. Geographic variation in the two-spot ladybird in England and Wales. Heredity, 21, 57-72.

CREED, E. R. 1971a. Melanism in the two-spot ladybird, Adalia bipunctata, in Great Britain. In: Creed, E. R. (ed.), Ecological Genetics and Evolution, Blackwell Scientific Publications, Oxford, pp. 134-151.
CREED, E. R. 1971b. Industrial melanism in the two-spot ladybird and smoke abatement. Evolution, 25, 290-293.

CREED, E. R. 1974. Two-spot ladybirds as indicators of intense local air pollution. Nature, 249, 390-392.

CREED, E. R. 1975. Melanism in the two-spot ladybird: the nature and intensity of selection. Proc. R. Soc. Lond. B, 190, 135-148.

DOBZHANSKY, T. 1933. Geographical variation in lady-beetles. Am. Nat., 67, 97-126.

Endler, J. A. 1986. Natural Selection in the Wild. Princeton University Press, Princeton.

HODEK, I. 1973. Biology of Coccinellidae. Academia, Prague.

HONEK, A. 1975. Colour polymorphism in Adalia bipunctata in Bohemia (Coleoptera: Coccinellidae). Ent. Germ., 1, 293-299.

HOSINO, Y. 1933. On the variation in the pattern of Harmonia axyridis. Zool. Mag., 45, 255-267 (in Japanese).

HosıNo, Y. 1936. Genetical study of the lady-bird beetle, Harmonia axyridis Pallas Rep. II. Jpn J. Genet., 12, 307-320 (in Japanese).

KEARNS, P. W. E., TOMLINSON, 1. P. M., O'DONALD, P. AND VELTMAN, C. J. 1990. Non-Random mating in the two-spot ladybird (Adalia bipunctata): I. A reassessment of the evidence. Heredity, 65, 229-240.

Koma1, т. 1956. Genetics of ladybeetles. Adv. Genet., 8, 155-188.

LEES, D. R., CREED, E. R. AND DUCKETT, J. G. 1973. Atmospheric pollution and industrial pollution and industrial melanism. Heredity, 30, 227-232.

LusIS, J. 1961. On the biological meaning of colour polymorphism of lady-beetle Adalia bipunctata L. Latv. Ent., 4, 3-29 (in Russian).

MAJERUS, M. E. N., O'DONALD, P., KEARNS, P. W. E. AND IRELAND, H. 1986. Genetics and evolution of female choice. Nature, 321, 164-167.

MAJERUS, M., O'DONALD, P. AND WEIR, J. 1982a. Evidence for preferential mating in Adalia bipunctata. Heredity, 49. 37-49.

MAJERUS, M. E. N., O'DONALD, P. AND Weir, J. 1982b. Female mating preference is genetic. Nature, 300, 521-523.

MANLy, B. F. J. 1985. The Statistics of Natural Selection on Animal Populations. Chapman and Hall, London.

MUGGLETON, J. 1978. Selection against the melanic morphs of Adalia bipunctata (two-spot ladybird): a review and some new data. Heredity, 40, 269-280.

MUGGLETON, J. 1979. Non-random mating in wild populations of polymorphic Adalia bipunctata. Heredity, 42, 57-65.

MUGGLETON, J., LONSDALE, D. AND BENHAM, B. R. 1975. Melanism in Adalia bipunctata L. (Col., Coccinellidae) and its relationship to atmospheric pollution. J. Appl. Ecol., 12, 451-464.

oвAтA, S. 1986. Determination of hibernation site in the ladybird beetle, Harmonia axyridis Pallas (Coleoptera, Coccinellidae). Kontyû, 54, 218-223.

OBATA, s. 1987. Mating behavior and sperm transfer in the ladybird beetle, Harmonia axyridis Pallas (Coleoptera: Coccinellidae). Appl. Ent. Zool, 22, 434-442.

овAтA, s. 1988. Mating refusal and its significance in females 
of the ladybird beetle, Harmonia axyridis. Physiol. Ent., 13, 193-199.

O'DONALD, P., DERRICK, M., MAJERUS, M. AND WEIR, J. 1984. Population genetic theory of the assortative mating, sexual selection and natural selection of the two-spot ladybird, Adalia bipunctata. Heredity, 52, 43-61.

O'DONALD, P. AND MUGGLETON, J. 1979. Melanic polymorphism in ladybirds maintained by sexual selection. Heredity, 43, 143-148.

okada, I., SAKaI, T., TANigishi, K. AND yoshida, T. 1973. Some observations on oviposition habits of a coccinellid beetle (Harmonia axyridis Pallas). Bull. Fac. Agr. Tamagawa Univ., 13, 63-71 (in Japanese).

osAWA, N. 1991. Ecological studies on the ladybird beetle Harmonia axyridis Pallas in a natural population. Ph.D. Thesis, Kyoto University (in Japanese).

PARTRIDGE, L. AND HALLIDAY, T. 1984. Mating patterns and mate choice. In: Krebs, J. R. and Davis, N. B. (eds) Behavioural Ecology, 2nd edn, Blackwell Scientific Publications, Oxford, pp. 222-250.
SASAJI, H. 1971. Fauna Japonica Coccinellidae (Insecta: Coleoptera). Academic Press of Japan, Tokyo.

SCALI, v. AND CREED, E. R. 1975. The influence of climate on mechanism in the Two-Spot ladybird, Adalia bipunctata, in central Italy. Trans. R. Ent. Soc. Lond., 127, 163-169.

SPENCER, H. G. 1988. Measuring mating preferences: the use of Manly's beta. Heredity, 60, 305-310.

STEWART, L. A. AND DIXON, A. F. G. 1989. Why big species of ladybird beetles are not melanic. Func. Ecol., 3, 165-177.

TAN, C.-C. 1949. Seasonal variations of color patterns in Harmonia axyridis. Proceedings of the 8th International Congress of Genetics, pp. 669-670. (Cited in Komai, 1956).

TAN, C.-C. AND LI, J.-C. 1934. Inheritance of the elytral color patterns in the lady-bird beetle, Harmonia axyridis Pallas. Am. Nat., 68, 252-265.

timoféeff-REssovsky, N. W. 1940. Zur Analyse des Polymorphismus bei Adalia bipunctata L. Biol. Zentr., 60, $130-137$. 